\title{
Effect of the Hydroalcoholic Extract of Winter Cherry Fruits (Physalis alkekengi) on Serum Lipid Profile and Paraoxonase Activity of Healthy
} Male Rats

\author{
Roya Keshtkaran, ${ }^{1}$ and Mahmood Vessal ${ }^{1,}{ }^{*}$ \\ ${ }^{1}$ Department of Biochemistry, Faculty of Basic Sciences, Shiraz Branch, Islamic Azad University, Shiraz, IR Iran \\ "Corresponding author: Dr. Mahmood Vessal, Ph.D., Department of Biochemistry, Faculty of Basic Sciences, Shiraz Branch, Islamic Azad University, Shiraz, IR Iran. E-mail: \\ mahmoodv@yahoo.com
}

Received 2016 September 18; Revised 2017 March 06; Accepted 2017 April 30.

\begin{abstract}
Background: Paraoxonase enzyme is attached to HDL and is involved in the maturation of this lipoprotein. This enzyme is activated by several antioxidants. These antioxidants exist in Winter cherry ( Physalis alkekengi). In fact, it contains a variety of antioxidants. Objectives: The objective of this study is to investigate the effects of a hydro-alcoholic extract of winter cherry fruits on serum lipid profile and paraoxanase1 (Pon1) activity in the rat.

Methods: In this randomized experimental study, hydroalcoholic extract of Physalis alkekengi fruits was obtained by a percolation method. Four groups of male Sprague Dawley rats $(260+/-5 \mathrm{~g})$, each containing 7 animals, were housed separately and fed standard rat chow and water ad libitum. Experiments were performed for 28 days on each group. Group1 (control1) received only the standard diet, with no hydroalcoholic extract. Group 2 (control 2) received $1 \mathrm{~mL}$ of water by gavage in addition to the standard diet. Groups 3 (experiment 1) and 4 (experiment2) received, respectively, 200 and $400 \mathrm{mg} / \mathrm{kg}$ b.w. of the extract in $1 \mathrm{~mL}$ of water through gavage. At the end of the experimental period, animals were fasted overnight and lipid profile and paraoxonase activity were determined and compared statistically by one way ANOVA and Tukey post hoc tests, using SPSS version 11.5

Results: Triglyceride, total cholesterol and LDL cholesterol were decreased dose dependently by the extract. HDL cholesterol and serum paraoxonase activities were increased significantly by Physalis extract.

Conclusions: The hydroalcoholic extract of Physalis alkekengi, possibly through the presence of antioxidants, increases paraoxonase activity and this enzyme, in turn, augments the level of HDL in serum.

Keywords: Fruit, Hydroalcoholic Extract, Serum, Lipid Profile, Paraoxonase 1(Aryldialkyl Phosphatase) Enzyme Activity, Physalis alkekengi
\end{abstract}

\section{Background}

In addition to the effects of the aqueous extract of winter cherry fruits (Physalis alkekengi) on the reduction of the activity of several estrogen induced enzymes [1-6], winter cherry fruits have also demonstrated free radical scavenging and lipid peroxidation inhibitory properties [7]. Using a 70\% methanolic extract of the fruit, Rashwan [8] reported the protective effects of a $600 \mathrm{mg} / \mathrm{kg}$ body weight (b.w.) of this extract on paracetamol induced liver injury as demonstrated by a significant increase in food consumption, weight gain, serum total protein and high density lipoprotein cholesterol (HDL-c). They also observed a decrease in malondialdehyde (MDA) and an increase in several antioxidant enzymes such as superoxide dismutase (SOD) and glutathione peroxidase (GpX). Significant decreases in serum low density lipoprotein cholesterol (LDLc), triglycerides and very low density lipoprotein cholesterol (VLDLP-c) were also observed compared to the paracetamol treated rats [8].
Paraoxonase-1 (PON-1) is one of the antioxidant enzymes which strongly prevents oxidation, hydrolyzes long chain fatty acids in phospholipids and by such an action inhibits LDL oxidation [9]. PON-1 is synthesized in the liver and is secreted in the serum where it is attached to HDL through its hydrophobic residues $[10,11]$. We had previously demonstrated that several flavonoids are able to significantly increase the activity of serum paraoxonase in male rats [12]. Medina-Medrano et al. [13] evaluated the phenolic constituents and the antioxidant properties of different parts of wild Physalis and presented a detailed review of the previous literature on the antioxidant properties of several other Physalis species including those of Physalis alkekengi. Therefore based on the presence of antioxidants in the calyces and fruits of this species and based on our own findings that several antioxidants increase PON-1 activity, we decided to study, for the first time, the effect of the hydroalcoholic extract of Physalis alkekengi fruits on serum paraoxonase activity of healthy male rats and to observe if 
there is going to be a corresponding significant increase in serum HDL-c followed by a significant diminution of total cholesterol, LDL-c and triglycerides upon such a treatment.

\section{Methods}

\subsection{Reagents}

Ethanol (96\%) was purchased from Ghadir Co. (Teheran, Iran). Tris- hydrochloride and calcium chloride were obtained from Merck (Darmsttadt, Germany). Paraoxon (diethyl paranitrophenyl phosphate) was secured from Sigma Chemical Co. (St. Louis, MO). Triglyceride and cholesterol kits were from Pars Azemoon (Teheran, Iran), Protein Kit was from Zist Chimie (Teheran, Iran), and LDL and HDL kits were obtained from Pishtaz Teb (Teheran, Iran).

\subsection{Preparation of Hydroalcoholic Extract}

Dried winter cherry fruits (Physalis alkekengi) were obtained from local herbalists, identified as previously mentioned [1] and was further confirmed by the Research Center of the Agriculture School of Shiraz University (Shiraz, Iran). The fruits were cleared from the dried sepals and calyces, washed with distilled water, dried at $70^{\circ} \mathrm{C}$ and pulverized. Five hundred milliliters of $70 \%$ ethanol was added to $100 \mathrm{~g}$ samples of pulverized winter cherry fruits in a percolator and left for 72 hours. The percolation was done as mentioned by Majekodunmi [14].

The extract produced was concentrated in a rotary evaporator at $35^{\circ} \mathrm{C}$ at a speed of 60 revolutions per minutes. The final mass of the viscous extract obtained from $100 \mathrm{~g}$ of the pulverized fruits was $4.6 \mathrm{~g}$.

\subsection{Experimental Animals}

Animal experiments were according to the ethics committee of our university. Adult male Sprague Dawley rats obtained from Shiraz University of Medical Sciences Animal quarters were acclimatized to the conditions of the animal house at $25^{\circ} \mathrm{C}$ and a light/dark cycle of 12 hours, while receiving standard rat chow (Pars Dam, Tehran, Iran) and water ad libitum. At the end of this period, the rats were weighed, 4 groups of seven rats each weighing $260+/-5 \mathrm{~g}$, were randomly assigned to different cages. Experiments were performed for 28 days on each group. Group1 (control1) received standard diet and water ad libitum, without any ethanolic extract. Group2 (control 2) were treated as in group1, except that, in addition, they also received $1 \mathrm{~mL}$ of water per day through stomach tube. Group 3 received every day, through gavage, $200 \mathrm{mg}$ of the the hydroalcoholic extract per kg b.w. in $1 \mathrm{~mL}$ water, while group 4 received , every day, $400 \mathrm{mg}$ of the hydroalcoholic extract per $\mathrm{kg}$ b.w. in $1 \mathrm{~mL}$ water through gavage. Rats were weighed every week. At the end of the 28th day, the rats were fasted overnight; blood was taken from the heart and the animals were sacrificed. Serum prepared from blood samples were kept at $-70^{\circ} \mathrm{C}$ for measuring the lipid profile and assaying for paraoxonase1 activity.

\subsection{Paraoxonase Assay}

The hydrolytic activity of serum Pon-1 enzyme was measured by the production of para-nitrophenol from diethyl p- nitrophenyl phosphate (paraoxan) according to the method of Beltowski et al. [15]. Briefly, to $460 \mu \mathrm{L}$ of $100 \mathrm{mM}$ Tris- $\mathrm{HCl}$ buffer containing $2 \mathrm{mM} \mathrm{CaCl}_{2}$ (pH 8.0), $40 \mu \mathrm{L}$ of serum and $500 \mu \mathrm{L}$ of $4 \mathrm{mM}$ paraoxon were added and the increase in absorbance at $412 \mathrm{~nm}$ was recorded after 2 minutes at $25^{\circ} \mathrm{C}$ against a blank containing the buffer instead of the serum. Using an extinction coefficient of $0.0182 \mathrm{~L} . \mu \mathrm{mole}^{-1} . \mathrm{cm}^{-1}$ for p-nitrophenol, enzyme units (U) were calculated in terms of nmoles of p-nitrophenol produced per min. per $\mathrm{ml}$ of the serum. Serum protein was measured by a kit (Zist Chimie, Teheran, Iran) based on Biuret method [16]. The specific activity of serum paraoxanase enzyme was reported as $\mathrm{U} / \mathrm{mg}$ serum protein.

\subsection{Measurement of Serum Triglycerides}

Using a kit (Pars Azemoon, Teheran, Iran), serum triglycerides was measured by Prestige 24i autoanalyzer (Japan). According to this method [17], serum triglycerides are hydrolyzed by lipoprotein lipase. Glycerol produced is converted to dihydroxy acetone phosphate and $\mathrm{H}_{2} \mathrm{O}_{2}$ in the presence of glycerol kinase and glycerol-phosphate oxidase. Hydrogen peroxide produced reacts with 4aminoantipyrine to form a quinine imine dye which is measured spectrophotometrically at $546 \mathrm{~nm}$.

\subsection{Measurement of Serum Total Cholestrol}

Using Pars Azemoon kit (Teheran, Iran), serum total cholesterol level was also measured by Prestige $24 \mathrm{i}$ autoanalyzer (Japan). In this method, cholesterol esters are first hydrolyzed by cholesterol esterase followed by oxidation of the free cholesterol by cholesterol oxidase which results in the formation of cholestenone and $\mathrm{H}_{2} \mathrm{O}_{2}$. Hydrogen peroxide reacts with 4-aminoantipyrine and phenol to produce quinine imine dye which is measured specrophotometrically at $546 \mathrm{~nm}$ [17].

\subsection{Measurement of HDL Cholesterol}

Pishtaz Teb kits (Teheran, Iran) were used for the enzymatic-colorimetric method of measuring HDL cholesterol [17]. According to this method, compounds with high 
affinity for LDL, VLDL and chylomicrons are added to prevent their participation in the reaction. A surfactant is then added which selectively accelerates the reaction of cholesterol esterase and cholesterol oxidase with HDL cholesterol to produce $\mathrm{H}_{2} \mathrm{O}_{2}$ which reacts as in previous section with 4aminoantipyrine and produces the colored quinine imine dye which is measured at $600 \mathrm{~nm}$.

\subsection{Measurement of LDL Cholesterol}

LDL cholesterol is also measured by a kit (Pishtaz Teb, Teheran, Iran) in which two different detergents are used. The first detergent blocks the reaction of HDL, VLDL and chylomicrons, while the second detergent accelerates the enzymatic reaction on LDL cholesterol to produce a colored quinine imine which is measured spectrophotometrically at $600 \mathrm{~nm}[18]$.

\subsection{Statistical Analysis}

Data were statistically analyzed by one way ANOVA and Tukey post hoc test using SPSS software (version 11.5; SPSS, Chicago, IL., USA). $\mathrm{P}<0.05$ was considered to be significant.

\section{Results}

The effects of gavage feeding of two doses of the hydroalcoholic extract of Physalis alkekengi fruits to rats on weight gain, and serum lipid profile after 4 weeks are shown in Table 1 . As noticed, the 2 doses of the extract had no significant effect on weight gain as compared with the 2 control groups. However, Physalis extract decreased serum triglyceride and LDL cholesterol levels dose dependently. Total cholesterol decreased gradually by the lower dose and this reduction reached a significant level when feeding $400 \mathrm{mg} / \mathrm{kg}$ b.w. of the extract per day. The reverse was true of the serum HDL cholesterol which was gradually increased at the lower dose and reached a significantly higher value compared to both control groups at the higher concentration of the extract.

The effects of 4 weeks of gavage feeding of 2 different levels of the extract on serum paraoxonase activity, serum protein content and the enzyme specific activity are shown in Table 2. As shown, both paraoxonase enzyme activities and specific activities were raised significantly upon feeding $200 \mathrm{mg} / \mathrm{kg}$ b.w. per day of the winter cherry extract. No further significant increase was noted in these two parameters at the higher level of the extract. Total serum protein level was decreased significantly upon feeding the lower dose, and no further significant decrease was noted upon doubling the dose.

\section{Discussion}

Apparently, feeding the hydroalcoholic extract of winter cherry fruits at the two levels produced no toxic effects as noted by lack of significant differences among gain in weight of the control groups and the animals fed two different doses of the extract (Table 1). The present study also demonstrates that the hydroalcoholic extract of Physalis alkekengi significantly decreases serum triglycerides, total cholesterol and LDL cholesterol, while increasing HDL cholesterol (Table 1) and paraoxonase activity (Table 2). Zarei et al. [19] noticed a significant decrease in serum total cholesterol and LDL cholesterol upon feeding 0.1, 0.2, and $0.3 \mathrm{~g}$ of the hydroalcoholic extract of winter cherry fruits per kg b.w. to a group of rats on a high fat diet. However, they were not able to report any significant effect of the extract on serum triglycerides and HDL cholesterol. In the present study, we noticed a significant increase in HDL cholesterol upon gavaging $400 \mathrm{mg}$ per $\mathrm{kg}$ b.w. of the extract for 28 days (Table 1). Our data on the effect of the hydroalcoholic extract of Physalis alkekengi fruits on serum lipid profile agrees well with those of $\mathrm{Na}$ et al. [20], who noticed the same trend of changes in serum lipid profile, when feeding single doses of 10,20, and $30 \mathrm{~g}$ of Physalis per $\mathrm{kg}$ b.w. to hyperlipidemic rats.

The increase in the activity of serum paraoxonase by the hydroalcoholic extract of Physalis alkekengi fruit could be due to its high antioxidant capacity as demonstrated by both Rashwan [8] and Medina- Mendrano et al. [13]. Also it could be due to the fairly high content of calcium ( $9 \mathrm{mg}$ per $100 \mathrm{~g}$ raw fruit), since paraoxonase is a Ca- dependent enzyme and upon activation by $\mathrm{Ca}^{++}$, it will increase serum HDL and decrease total cholesterol [21].

We suggest that this preliminary work to be followed by using several higher doses of the extract to find out if the increase in the activity and the specific activity of the serum paraoxonase follow a dose dependent pattern. 
Table 1. Effects of 4 Weeks of Gavage Feeding of the Hydroalcholic Extract of Physalis alkakengi Fruits on Body Weight and Serum Lipid Profiles of Adult Healthy Male Rats ${ }^{\mathrm{a}, \mathrm{b}}$

\begin{tabular}{|c|c|c|c|c|c|c|c|}
\hline Experimental Group & $\mathbf{N}$ & Body Weight 1st day, g & $\begin{array}{l}\text { Body Weight 28th day, } \\
\text { g }\end{array}$ & $\mathrm{TG}, \mathbf{m g} / \mathbf{d L}$ & $\begin{array}{c}\text { Total Cholesterol, } \\
\text { mg/dL }\end{array}$ & LDL- C, mg/dL & HDL-C, mg/dL \\
\hline Control 1 (-extract) & 7 & $262 \pm 6 a$ & $322 \pm 11 a$ & $98.9 \pm 3.2 \mathrm{a}$ & $65.6 \pm 1.0 \mathrm{a}$ & $21.7 \pm 0.9 a$ & $24.2 \pm 1.1 \mathrm{a}$ \\
\hline $\begin{array}{l}\text { Control } 2 \text { (-extract }+1 \\
\left.\mathrm{ml} \mathrm{H}_{2} \mathrm{O}\right)\end{array}$ & 7 & $265 \pm 6 a$ & $305 \pm 5 a$ & $97.8 \pm 3.0 \mathrm{a}$ & $65.1 \pm 1.5 a$ & $20.5 \pm 0.7 a$ & $25.5 \pm 1.1 \mathrm{a}$ \\
\hline $\begin{array}{l}\text { Experiment } 1(200 \mathrm{mg} \\
\left.\text { extract per } \mathrm{ml}_{2} \mathrm{O}\right)\end{array}$ & 7 & $260 \pm 6 a$ & $302 \pm 7 a$ & $79.8 \pm 2.5 b$ & $61.1 \pm 2.4 \mathrm{ab}$ & $17.4 \pm 0.9 \mathrm{~b}$ & $27.8 \pm 1.5 \mathrm{ab}$ \\
\hline $\begin{array}{l}\text { Experiment } 2(400 \mathrm{mg} \\
\left.\text { extract/mL } \mathrm{H}_{2} \mathrm{O}\right)\end{array}$ & 7 & $254 \pm 8 a$ & $304 \pm 2 a$ & $67.3 \pm 3.4 \mathrm{c}$ & $57.9 \pm 1.0 b$ & $13.4 \pm 0.4 \mathrm{c}$ & $31.0 \pm 2.0 \mathrm{~b}$ \\
\hline Anova p values & & 0.183 & 0.144 & 0.006 & 0.001 & 0.001 & 0.001 \\
\hline
\end{tabular}

Abbreviations: HDL-C, high density lipoprotein cholesterol; LDL-C, low density lipoprotein cholesterol; N, number of animals in each group; TG, triglycerides.

${ }^{a}$ Values are expressed as mean \pm SEM

${ }^{\mathrm{b}}$ In each column, values with different letters $(\mathrm{a}, \mathrm{b}, \mathrm{c}, \ldots)$ are significantly different from the control values.

Table 2. The Effects of 4 Weeks of Gavage Feeding of the Hydroalcoholic Extract of Physalis alkekengi Fruits on Serum Paraoxonase Activity, Serum Protein and Paraoxonase Specific Activity of Adult Healthy Male Rats ${ }^{\mathrm{a}, \mathrm{b}}$

\begin{tabular}{|c|c|c|c|c|}
\hline Experimental Group & $\mathbf{N}$ & Paraoxanase Activity, U/mL & Serum Protein, $\mathrm{mg} / \mathrm{mL}$ & Paraoxonase Specific Activity, U/mg Protein \\
\hline Control 1 (-extract) & 7 & $107.9 \pm 8.7 \mathrm{a}$ & $72.5 \pm 0.9 \mathrm{a}$ & $1.5 \pm 0.1 \mathrm{a}$ \\
\hline Control 2 (-extract $+1 \mathrm{~mL} \mathrm{H}_{2} \mathrm{O}$ ) & 7 & $112.4 \pm 8.3 \mathrm{a}$ & $71.6 \pm 1.1 \mathrm{a}$ & $1.6 \pm 0.1 \mathrm{a}$ \\
\hline Experiment $1(+200 \mathrm{mg} / \mathrm{mL}$ extract $)$ & 7 & $182.4 \pm 3.0 \mathrm{~b}$ & $66.1 \pm 1.0 \mathrm{~b}$ & $2.8 \pm 0.1 \mathrm{~b}$ \\
\hline Experiment $2(+400 \mathrm{mg} / \mathrm{mL}$ extract $)$ & 7 & $186.9 \pm 4.0 \mathrm{~b}$ & $64.6 \pm 1.3 b$ & $2.9 \pm 0.1 \mathrm{~b}$ \\
\hline Anova P values & & $<0.001$ & $<0.001$ & 0.001 \\
\hline
\end{tabular}

Abbreviations: $\mathrm{N}$, number of animals in each group; $\mathrm{U}$, enzyme unit.

${ }^{a}$ Values are expressed as mean \pm SEM.

${ }^{b}$ In each column, values with different letters (a, b, c,....) are significantly different from the control values.

\section{Acknowledgments}

This investigation was extracted from Roya Keshtkaran's MSc. thesis (code: 16330520931007) submitted to the graduate school of Shiraz Azad university as a partial fulfillment of the requirements for the degree of master of science in biochemistry. Dr. Mahmood Vessal acted as her thesis advisor.

\section{Footnotes}

Authors' Contribution: Dr. Mahmood Vessal designed the experiments and wrote the paper, while Ms. Roya Keshtkaran performed the experiments.

Conflict of Interest: No conflict of interest

Funding/Support: This investigation was partially supported by the office of vice chancellor for research, Shiraz Azad University, Shiraz. Iran.

\section{References}

1. Vessal M, Mehrani HA, Omrani GH. Effects of an aqueous extract of Physalis alkekengi fruit on estrus cycle, reproduction and uterine cre- atine kinase BB-isozyme in rats. J Ethnopharmacol. 1991;34(1):69-78. [PubMed: 1753789].

2. Vessal M, Mostafavi-Pour Z, Kooshesh F. Age and sex dependence of the effects of an aqueous extract of Physalis alkekengi fruits on rat hepatic glucose 6-P dehydrogenase activity. Comparat Biochem Physiol Part B Biochem Mol Biol. 1995;111(4):675-80. doi: 10.1016/03050491(95)00004-r.

3. Vessal M, Yazdanian M. Comparison of the effects of an aqueous extract of Physalis alkekengi fruits and/or various doses of 17-betaestradiol on rat estrous cycle and uterine glucose 6-phosphate dehydrogenase activity. Comp Biochem Physiol C Pharmacol Toxicol Endocrinol. 1995;112(2):229-36. [PubMed: 8788592].

4. Vessal M, Rasti M, Kooshesh F. Modulation of the pituitary and basomedial hypothalamic lysyl-aminopeptidase activities be betaestradiol and/or an aqueous extract of Physalis alkekengi fruits. Comp Biochem Physiol B Biochem Mol Biol. 1996;115(2):267-71. [PubMed: 8998678].

5. Vessal M, Rasti M. Estradiol antagonistic effects of winter cherry extract on pituitary and hypothalamic G6PD activities. Iran J Med Sci. 1995;20:152-8.

6. Vessal M, Khoshdel Z, Fathi N. Effects of an aqueous extract of Physalis alkekengi fruits on the activity of ovarian 3-beta and 20- alpha hydroxysteroid dehydrogenases in late pregnancy in rat. Iran J Med Sci. 2004;29:175-9.

7. Laczko-Zold E, Zupko I, Rethy B, Csedo K, Hohmann J. [Antioxidant activity of the fruits and hydrophilic compounds of Physalis alkekengi]. Acta Pharm Hung. 2009;79(4):169-73. [PubMed: 20183952]. 
8. Rashwan NM. Effect of Physalis and choline on lipid profile and antioxidant activity in hepatic toxicity of rats. Aust J Basic Appl Sci. 2012;6(8):654-60.

9. Altındag O, Karakoc M, Soran N, Celik H, Celik N, Selek S. Paraoxonase and Arylesterase Activities in Patients with Rheumatoid Arthritis. Romatizma/Rheumatism. 2007;22(4).

10. Gugliucci A, Menini T. Paraoxonase 1 and HDL maturation. Clin Chim Acta. 2015;439:5-13. doi: 10.1016/j.cca.2014.09.016. [PubMed 25261854].

11. Harel M, Brumshtein B, Meged R, Dvir H, Ravelli RB, McCarthy A, et al.3 D structure of serum paraoxonase 1 sheds light on its activity, stability, solubility and crystallizability. Arh Hig Rada Toksikol. 2007;58(3):34753. doi: 10.2478/v10004-007-0028-0. [PubMed: 17913690].

12. Hamidia Z, Nayeri H, Vessal M, Naderi G, Boshtam M. Myricetin quercetin, kaempferol and galangin all increase serum paraoxonase activity. Indian J Fundament Appl Life Sci. 2013;3(1):36-43.

13. Medina-Medrano JR, Almaraz-Abarca N, Gonzalez-Elizondo MS, Uribe-Soto JN, Gonzalez-Valdez LS, Herrera-Arrieta Y. Phenolic constituents and antioxidant properties of five wild species of Physalis (Solanaceae). Bot Stud. 2015;56(1):24. doi: 10.1186/s40529-015-0101-y. [PubMed: 28510833].

14. Majekodunmi SO. Review of extraction of medicinal plants for pharmaceutical research. Merit Res J Med Med Sci. 2015;3(11):521-7.
15. Beltowski J, Wojcika G, Jamroz A. Effect of 3-hydroxy-3-methyl glutaryl coenzyme A inhibitors (statins) on tissue paroxonase1 and plasma platelet activating factor acetyl hydrolase activities.J Cardiovasc Pharmacol. 2004;43(1):121-7.

16. Silverman LM, Christenson RH, Grant GH. Amino acids and proteins. Textbook of clinical chemistry. WB Saunders; 1986.

17. Rifai N, Warnick GR. In: Tietz textbook of clinical chemistry and molecular diagnostics. Burtis CA, Ashwood ER, Bruns DE, editors. ; 2006. Lipids, lipoproteins, apolipoproteins, and other cardiovascular risk factors.

18. Rifai N, Iannotti E, DeAngelis K, Law T. Analytical and clinical performance of a homogeneous enzymatic LDL-cholesterol assay compared with the ultracentrifugation-dextran sulfate-Mg2+ method. Clin Chem. 1998;44(6 Pt1):1242-50. [PubMed: 9625048].

19. Zarei A, Ashtiyani S, Mohamadi AA, Gabari A. The effects of Physalis Alkekengi extract on lipids concentrations in rats. Arak Med Univ J. 2011;14(2):36-42.

20. Na Z, Zhi- min B, Hong- Juan G, Yu Z, Wenjing Q, Hong- bo MA. Protective effect of Physalis on experimental rats with hyperlipidemia.JJilin Med College. 2008;3:12.

21. Gonzalvo MC, Gil F, Hernández AF, Villanueva E, Pla A. Inhibition of paraoxonase activity in human liver microsomes by exposure to EDTA, metals and mercurials. Chemico Biol Interact. 1997;105(3):169-79. 